\title{
Variations in biomass, nutrient contents and nutrient use efficiency among Chinese fir provenances
}

\author{
By Pengfei Wu ${ }^{1)}$, Mulualem Tigabu ${ }^{2)}$, Xiangqing MA ${ }^{\left.1),{ }^{*}\right)}$, Per Christer Odén ${ }^{2)}$, \\ Youlan $\mathrm{HE}^{1)}$, XINTUO YU ${ }^{1)}$ and ZHIYING $\mathrm{HE}^{1)}$
}

(Received $11^{\text {th }}$ February 2010)

\begin{abstract}
A provenance trial involving 16 Chinese fir provenances was established in southern China in 1979, and biomass, nutrient content and nutrient use efficiency were assessed at the age of 23 . One-way analysis of variance revealed significant inter-provenance variation $(\mathrm{p}<0.0001)$ in measured variables. The mean total biomass ranged from $98.8 \pm 5.3$ to $163.3 \pm 4.2 \mathrm{t} \mathrm{ha}^{-1}$, and the stemwood accounted for $47-65 \%$ of the total biomass, followed by roots (11-24\%), stembark (7.4-13.7\%), and needles and branches $(<10 \%)$. Much of the nitrogen, phosphorus and potassium were stored in the needles, although the concentration varies among provenances. Whole-tree nutrient use efficiency varied from $115.4 \pm 2.1$ to $180.2 \pm 1.02 \mathrm{~g} \mathrm{~g}^{-1}$, while efficiency in stemwood production ranged from $53.9 \pm 3.1$ to $106.3 \pm 1.1 \mathrm{~g} \mathrm{~g}^{-1}$. Provenances did not display consistent variation in all measured variables, suggesting the need for multiple criteria for selection in future tree improvement program. In conclusion, the study reveals the existence of considerable variation in biomass production and nutrient use efficiency among Chinese fir provenances that can be exploited for selecting desirable genotypes for enhancing productivity of Chinese fir plantations.
\end{abstract}

Key words: Biomass production; Cunninghamia lanceolata; Tree improvement; forest nutrition.

\section{Introduction}

Chinese fir (Cunninghamia lanceolata (Lamb.) Hook.) is a fast-growing evergreen coniferous tree with high yield and excellent wood quality. Its natural distribution ranges from $34^{\circ} 03^{\prime} \mathrm{N}$ to $20^{\circ} 41^{\prime} \mathrm{N}$ latitude, distribute among 16 Provinces in China. The planting history of Chinese fir extends over more than 1000 years (Wu, 1984), but the area under Chinese fir plantations has expanded rapidly since the 1980s (ZHANG et al., 2004). Chinese fir plantations are usually established for industrial timber production with a short rotation period of 20-25 years. Many short rotation plantations that

\footnotetext{
1) Forestry College, Fujian Agriculture and Forestry University, Fuzhou, 350002 Fujian Province, PR China. E-mail: lxymxq@126.com

$\left.{ }^{2}\right)$ Swedish University of Agricultural Sciences, Faculty of Forest Sciences, Southern Swedish Forest Research Centre, PO Box 49, SE-230 53 Alnarp, Sweden. E-mail: Mulualem.tigabu@ess. slu.se; per.oden@ess.slu.se

*) Corresponding author: Dr. MA XIANGQING. Forestry College, Fujian Agriculture and Forestry University Fuzhou, 350002, Fujian Province, P. R. China. Tel: +86 591 83789865; Fax: +86 591 83780261; Mobile Phone: 13799408187. E-mail: lxymxq@ $\underline{126 . \mathrm{com}}$
}

couple intensive management may lead to high rates of nutrient removal during harvesting, thus raising concerns about tree nutrient utilization efficiencies (WANG et al., 1991).

The decline in yield of Chinese fir over successive rotations has been recognized and become a major concern among forest managers and scientists (MA et al., 2000a, 2002, 2003; TIAN et al., 2002). The standing wood volume of the second and third rotations of Chinese fir plantation decreased by $30 \%$ and $47 \%$, respectively, compared to the first rotation (CHEN, 1983). The dominant tree height of the second and third rotation of Chinese fir was reduced by $7 \%$ and $23 \%$, respectively compared to the first rotation (FANG, 1987). In addition, degradation in soil physical, chemical, biological and biochemical properties under successive rotations of Chinese fir have been widely reported (YANG et al., 1996; YING, 1997; MA et al., 2000b; YU et al., 2000; Sun et al., 2003; ZHANG et al., 2004).

The traditional provenance trial for timber plantation mainly focused on tree growth and biomass productivity, but paid little attention to nutrient use efficiency of trees (ANONYMOUs, 1991, 994; Li et al., 1993). A range wide provenance variation in growth, photosynthesis, and transpiration of Chinese fir has been observed (YU, 1997; SHEN et al., 1994). The patterns of biomass distribution in Chinese fir stands and the magnitude of nutrient loss associated with harvesting method have also been characterized (LI et al., 1994; YING, 2004; YANG, 1999; YANG, 2000). However, these studies have rarely continued beyond comparison of total stand yield or conclusion of the order of biomass in tree components. Detailed information about biomass productivity and nutrient use efficiency of different provenances is still scarce. Thus, this study was carried out to characterize variations in biomass distribution and nutrient use efficiency among 16 Chinese fir provenances to identify fast-growing genotypes that have good nutrient-use efficiency and woody biomass productivity.

\section{Materials and Methods \\ Study site}

The study was carried out in a Chinese fir plantation established at the Xiqin Teaching Forest Farm $\left(26^{\circ} 40^{\prime} \mathrm{N}\right.$, $\left.118^{\circ} 10^{\prime} \mathrm{E}\right)$ of Fujian Agriculture and Forestry University, Nanping city in central Fujian Province, southern China. The climate of the study site is subtropical monsoon type, with an annual average temperature of $19.4^{\circ} \mathrm{C}$ and an annual average rainfall of $1786 \mathrm{~mm}$. The average annual relative humidity is $81 \%$, mean length 
Table 1. - Geographic locations and climatic conditions (mean annual rainfall and mean annual temperature) of the different provenances of Chinese fir included in the trial.

\begin{tabular}{|c|c|c|c|c|c|c|}
\hline & latitudinal zone & Provenance & $\begin{array}{l}\text { Latitude } \\
\qquad\left({ }^{\circ} \mathrm{N}\right)\end{array}$ & $\begin{array}{l}\text { Longitude } \\
\quad\left({ }^{\circ} \mathrm{E}\right)\end{array}$ & $\begin{array}{l}\text { Rainfall } \\
\qquad(\mathrm{mm})\end{array}$ & $\begin{array}{c}\text { Temperature } \\
\left({ }^{\circ} \mathrm{C}\right)\end{array}$ \\
\hline \multirow{5}{*}{ I } & \multirow{5}{*}{ South Subtropic } & Pubei, Guangxi & 22.25 & 109.52 & 1804.3 & 21.4 \\
\hline & & Wenshan, Yunnan & 23.38 & 104.25 & 962.2 & 17.8 \\
\hline & & Huaiji, Guangdong & 23.93 & 112.18 & 1713.2 & 20.9 \\
\hline & & Changtai, Fujian & 24.62 & 110.73 & 1469.2 & 21.0 \\
\hline & & Rongshui, Guangxi & 25.13 & 109.23 & 1769.1 & 19.3 \\
\hline \multirow{6}{*}{ II } & \multirow{6}{*}{ Middle Subtropic } & Quannan, Jiangxi & 24.76 & 114.52 & 1515.6 & 18.9 \\
\hline & & Nanping, Fujian & 26.67 & 118.17 & 1679.2 & 19.3 \\
\hline & & Jinping, Guizhou & 26.68 & 108.18 & 1375.3 & 16.5 \\
\hline & & Chenxi, Hunan & 28.02 & 110.18 & 1401.3 & 16.9 \\
\hline & & Enshi, Hubei & 30.27 & 109.37 & 1518.8 & 16.3 \\
\hline & & Xuyong, Sichuan & 28.14 & 105.47 & 1175.8 & 18.0 \\
\hline \multirow{5}{*}{ III } & \multirow{5}{*}{ North Subtropic } & Kaihua, Zhejiang & 29.03 & 118.42 & 1704.1 & 16.4 \\
\hline & & Jiande, Zhejiang & 29.55 & 118.27 & 1440.4 & 17.0 \\
\hline & & Xiuning, Anhui & 29.77 & 118.18 & 1642.8 & 16.3 \\
\hline & & Luoshan, Henan & 32.22 & 114.55 & 1032.3 & 15.2 \\
\hline & & Shangcheng, Henan & 34.78 & 115.42 & 1197.5 & 15.5 \\
\hline
\end{tabular}

of the growing season (sum of days with a daily mean temperature $>5^{\circ} \mathrm{C}$ ) is 300 days, and the frost season begins from the first ten days of November to early March of the second year. The stands are located at 150-200 m altitude on a slope of $25^{\circ}$. The soils were classified as mountainous red clay loam covered with thin humus, acidic oxisols. The Chinese fir plantation was established in 1979 using seeds obtained from 16 provenances in 13 provinces (Table 1). Pubei, Wenshan, Huaiji, Changtai and Rongshui represent the southern range of distribution of the species, Quannan, Nanping, Jinping, Chenxi, Enshi and Xuyong represent the central range, and Kaihua, Jiande, Xiuning, Luoshan and Shangcheng represent the northern distribution range (Figure 1). The planting site was divided into four blocks and with each block 16 plots were laid. Within a block, provenances were randomly assigned to the plots and 21 seedlings from each provenance were planted in each plot.

\section{Estimation of tree biomass and nutrient analyses}

The trial was assessed at the age of 23 years for height and diameter at breast height $(\mathrm{DBH})$ of every tree in each plot. The mean average tree was used to estimate stand biomass as DBH and height did not vary much within each stand (MA et al., 2007). The average trees were felled at the ground level using a mechanical chain saw and the roots carefully dug out from the different soil layers and washed with water. Aboveground part of sample tree was classified as stemwood, stembark, live branches, dead branches and needles. Fresh weights of all the tree components were weighed in the

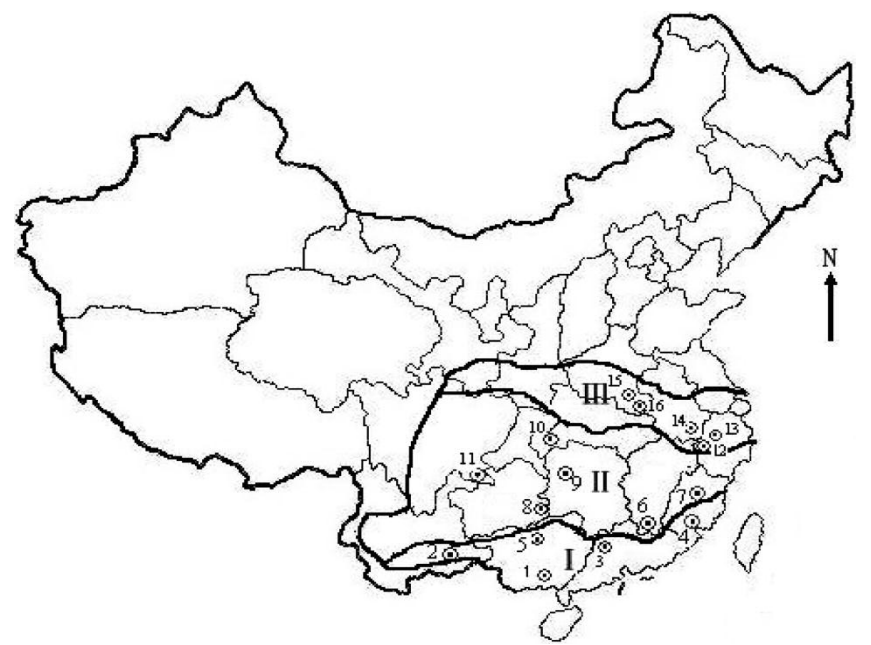

Figure 1. - Natural distribution of Chinese fir (I, II, III) and provenances represented in the trial (1: Pubei, 2: Wenshan, 3: Huaiji, 4: Changtai, 5: Rongshui, 6: Quannan, 7: Nanping, 8: Jinping, 9: Chenxi, 10: Enshi, 11: Xuyong, 12: Kaihua, 13: Jiande, 14: Xiuning, 15: Luoshan, 16: Shangcheng). 
field and then sub-sampled for determination of the dry mass and nutrient concentrations. All samples were dried at $80^{\circ} \mathrm{C}$ to constant weight to determine the biomass. Biomass of all tree components was summed to obtain the mean tree biomass. It was then multiplied by the number of trees per plot and extrapolated to a hectare (KUMAR et al., 1998; SHUJAUDDIN et al., 2003).

Following dry weight determination, plant tissue samples were ground to pass a $1 \mathrm{~mm}$ mesh prior to chemical analyses. Triplicate samples were analyzed for $\mathrm{N}, \mathrm{P}$ and K. Total nitrogen was determined by micro-Kjeldahl technique (PEACH and Tracy, 1956; MisRa, 1968). Phosphorus and potassium were extracted by wet ashing of $0.5 \mathrm{~g}$ plant material in an acid mixture consisting of 10 $\mathrm{ml} \mathrm{H}_{2} \mathrm{SO}_{4}, 3 \mathrm{ml} \mathrm{HNO}_{3}$ and $1 \mathrm{ml} \mathrm{HClO}_{4}$, following the method of LACKSON (1958). Phosphorus was determined following the molybdenum-blue method and potassium by flame photometry.

\section{Data analysis}

Nutrient contents of plant parts were calculated as the product of nutrient concentrations and plant dry matter. The stand nutrient content was obtained by multiplying each biomass fraction by the respective nutrient concentration and finally summing the contents of the individual fractions. The nutrient use efficiency (NUE) was calculated by two different equations based on the total amount of nutrient content in the stand biomass for whole tree as a quantity of total biomass built per unit of the nutrient in the biomass (WANG et al., 1991; VitouseK, 1982), and stem wood as a quantity of stem wood biomass produced per unit of nutrient in the biomass (HERBERT, 1996; AERTS, 1989) as follows:

Whole-tree NUE = dry biomass of stand/ nutrient content of stand

Stem wood NUE = stem wood biomass of stand/ nutrient content of stand

Table 2. - Estimates of variance components as percentage of the total variation, and phenotypic coefficient of variation (PCV) for biomass, nutrient content (Nitrogen, Phosphorus and Potassium) and nutrient use efficiency (NUE).

\begin{tabular}{|c|c|c|c|c|}
\hline \multirow[b]{2}{*}{ Trait } & \multicolumn{4}{|c|}{ Variance component (\%) } \\
\hline & Grand Mean & Provenance & Error & $\mathrm{PCV}(\%)$ \\
\hline \multicolumn{5}{|c|}{ Biomass $\left(\right.$ t ha $\left.^{-1}\right)$} \\
\hline Needle & 7.6 & 95.1 & 4.9 & 40.1 \\
\hline Live branch & 10.3 & 93.1 & 6.9 & 37.3 \\
\hline Dead branch & 3.4 & 95.8 & 4.2 & 48.6 \\
\hline Bark & 13.1 & 87.1 & 12.9 & 25.7 \\
\hline Stem wood & 75.8 & 56.5 & 43.5 & 13.3 \\
\hline Root & 21.3 & 89.3 & 10.7 & 30.4 \\
\hline Total & 131.5 & 88.2 & 11.8 & 15.8 \\
\hline \multicolumn{5}{|c|}{ Nitrogen content ( $\mathrm{g} \mathrm{kg}^{-1}$ ) } \\
\hline Needle & 14.9 & 79.7 & 20.3 & 14.0 \\
\hline Live branch & 7.6 & 91.7 & 8.3 & 31.0 \\
\hline Dead branch & 4.0 & 93.3 & 6.7 & 32.9 \\
\hline Bark & 6.7 & 94.5 & 5.5 & 36.6 \\
\hline Stem wood & 2.5 & 80.5 & 19.5 & 46.1 \\
\hline Root & 7.6 & 88.3 & 11.7 & 24.3 \\
\hline \multicolumn{5}{|c|}{ Phosphorus content $\left(\mathrm{g} \mathrm{kg}^{-1}\right)$} \\
\hline Needle & 1.1 & 96.2 & 3.8 & 43.4 \\
\hline Live branch & 0.8 & 97.2 & 2.8 & 49.6 \\
\hline Dead branch & 0.2 & 98.1 & 1.9 & 127.9 \\
\hline Bark & 0.6 & 96.7 & 3.3 & 58.0 \\
\hline Stem wood & 0.2 & 99.8 & 0.2 & 119.3 \\
\hline Root & 0.5 & 97.3 & 2.7 & 57.1 \\
\hline
\end{tabular}


Table 2. - Continued.

\begin{tabular}{|c|c|c|c|c|}
\hline \multirow[b]{2}{*}{ Trait } & \multicolumn{4}{|c|}{ Variance component $(\%)$} \\
\hline & Grand Mean & Provenance & Error & $\operatorname{PCV}(\%)$ \\
\hline \multicolumn{5}{|c|}{ Potassium content $\left(\mathrm{g} \mathrm{kg}^{-1}\right)$} \\
\hline Needle & 5.3 & 87.0 & 13.0 & 18.7 \\
\hline Live branch & 3.4 & 89.1 & 10.9 & 22.1 \\
\hline Dead branch & 0.9 & 96.6 & 3.4 & 41.8 \\
\hline Bark & 2.5 & 95.4 & 4.6 & 36.2 \\
\hline Stem wood & 0.9 & 97.3 & 2.7 & 43.4 \\
\hline Root & 3.3 & 83.0 & 17.0 & 19.7 \\
\hline \multicolumn{5}{|c|}{ NUE-whole tree $\left(\mathrm{g} \mathrm{g}^{-1}\right)$} \\
\hline Nitrogen & 211.3 & 96.5 & 3.5 & 15.9 \\
\hline Phosphorus & 3573.4 & 99.2 & 0.8 & 46.3 \\
\hline Potassium & 548.1 & 97.0 & 3.0 & 18.4 \\
\hline Overall NUE & 143.6 & 95.5 & 4.5 & 13.9 \\
\hline \multicolumn{5}{|c|}{ NUE-stem wood $\left(\mathrm{g} \mathrm{g}^{-1}\right)$} \\
\hline Nitrogen & 123.6 & 90.2 & 9.8 & 21.5 \\
\hline Phosphorus & 2086.5 & 97.4 & 2.6 & 48.8 \\
\hline Potassium & 319.9 & 90.9 & 9.1 & 23.4 \\
\hline Overall NUE: & 83.9 & 88.2 & 11.8 & 19.6 \\
\hline
\end{tabular}

One-way Analyses of variance was used to determine whether biomass, nutrient content and nutrient utilization efficiency differ significantly among provenances using SPSS Statistical Package (SPSS 13.0, SPSS Inc., IL, U.S.A.). Means that exhibited significant differences were compared using Tukey's test at $5 \%$ level of significance. The magnitude of variation, as percentage of the total variation, due to provenance or environment (error) was quantified for each trait using the restricted maximum likelihood method, and the phenotypic coefficient of variation was computed based on the overall mean and the total variance for each trait.

\section{Results}

\section{Biomass production}

Significant differences $(p<0.001)$ among Chinese fir provenances were detected for total biomass and biomass of various tree components. The magnitude of variation due to provenance was higher for total biomass and biomass of various tree components except stemwood biomass, although its phenotypic coefficient of variation was comparable to that of total biomass (Table 2 ). The mean total biomass ranged from $98.8 \pm 5.3 \mathrm{t} \mathrm{ha}^{-1}$ to $163.3 \pm 4.2 \mathrm{t} \mathrm{ha}^{-1}$. The highest mean total biomass was recorded for Changtai and Xiuning while the lowest value was recorded for Kaihua and Jiande (Figure 2). For needles, the mean biomass varied from $2.8 \pm 0.2 \mathrm{t}$ $\mathrm{ha}^{-1}$ to $12.5 \pm 0.8 \mathrm{t} \mathrm{ha}^{-1}$, and Changtai, Shangcheng and Chenxi recorded the highest value while Xuyong, Kaihua and Huaiji recorded the lowest. The mean biomass of live branches ranged from $4.9 \pm 0.4 \mathrm{t} \mathrm{ha}^{-1}$ to $17.3 \pm 1.4 \mathrm{t} \mathrm{ha}^{-1}$, and Changtai recorded the highest while Xuyong and Kaihua the least values for this trait. For dead branches, the mean biomass varied from $0.9 \pm 0.1 \mathrm{t} \mathrm{ha}^{-1}$ (Shangcheng) to $5.9 \pm 0.3 \mathrm{t} \mathrm{ha}^{-1}$ (Enshi). For stembark, the mean biomass ranged from $9.0 \pm 0.9 \mathrm{t}$ $\mathrm{ha}^{-1}$ to $19.1 \pm 1.9 \mathrm{t} \mathrm{ha}^{-1}$. Wenshan, Xiuning and Pubei had the highest value for this trait while the lowest value was recorded for Kaihua, Huaiji and Quannan. The mean stemwood biomass varied between $58.3 \pm 5.8 \mathrm{t}$ $\mathrm{ha}^{-1}$ (Jiande) and $87.2 \pm 6.9 \mathrm{t} \mathrm{ha}^{-1}$ (Xiuning). The mean root biomass varied between $14.2 \pm 0.7 \mathrm{t} \mathrm{ha}^{-1}$ and $39.4 \pm 4.7 \mathrm{t} \mathrm{ha}^{-1}$; Changtai had the highest value while Rongshui, Kaihua and Huaiji had the lowest value for this trait. Ranking of provenances did not show a consistent trend for all biomass estimates. However, Kaihua, Xuyong and Jiande ranked the lowest for most biomass estimates while Xiuning, Changtai and Wenshan recorded the highest values.

In all provenances, much of the biomass was accumulated in the stem wood, which accounted for $46.6 \%$ to 


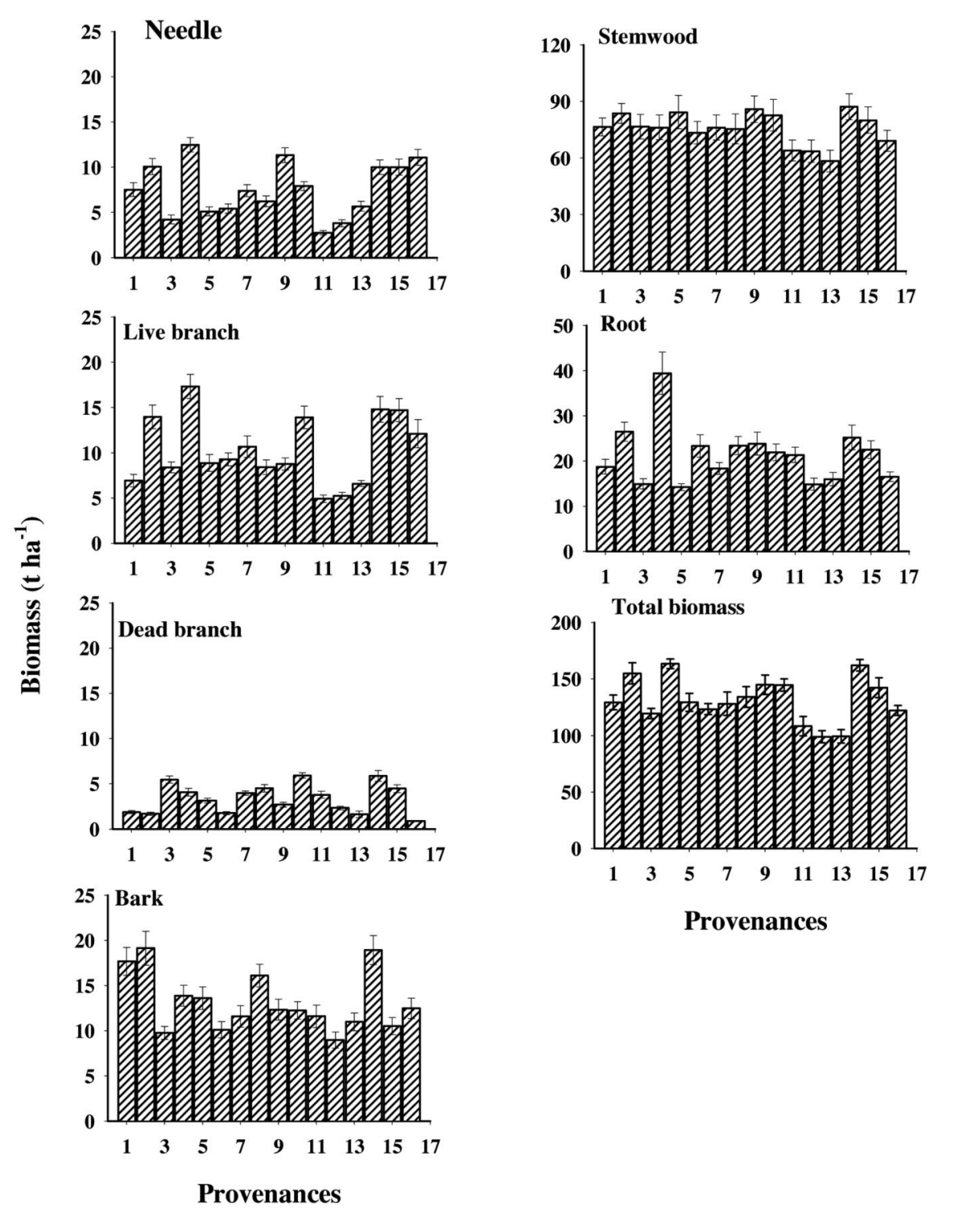

Figure 2. - Total biomass accumulation $\left(\mathrm{t} \mathrm{ha}^{-1}\right)$ and biomass of various tree components for 16 Chinese fir provenances (mean $\pm \mathrm{se}$ ).

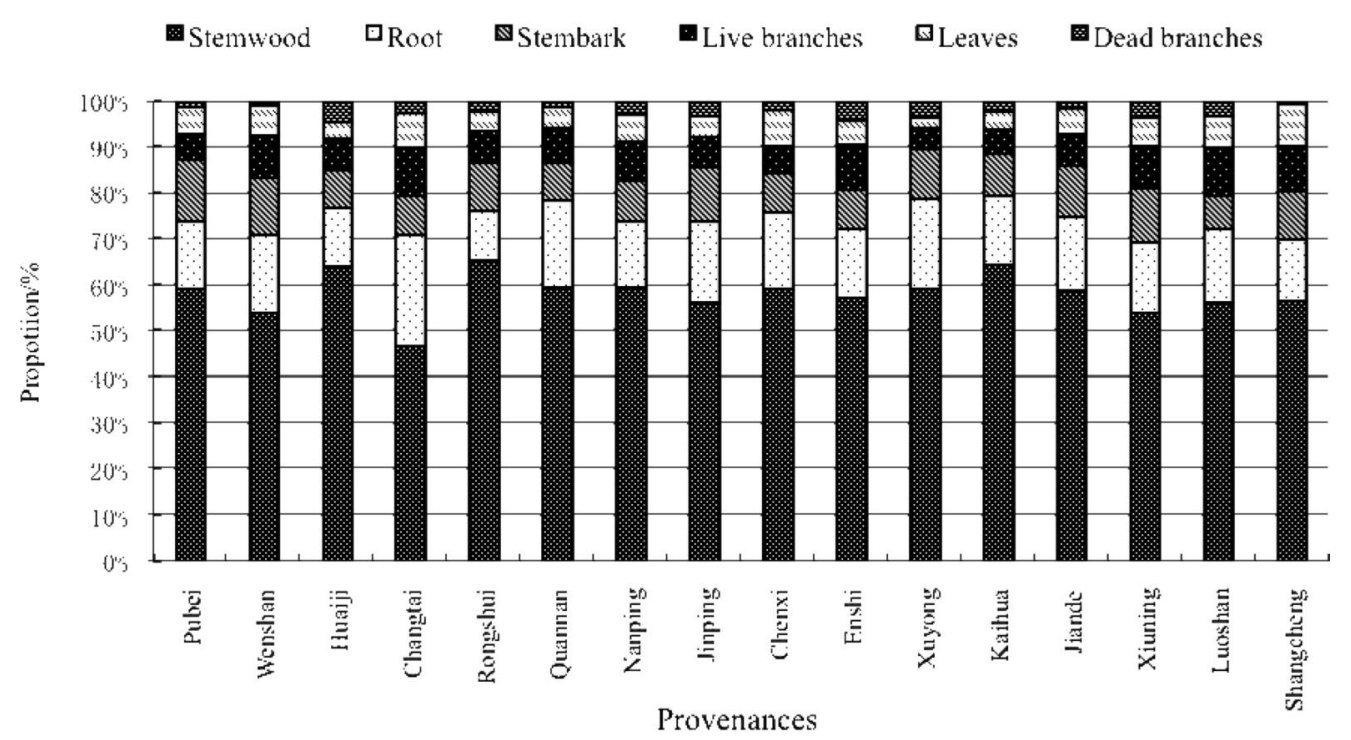

Figure 3. - Biomass distribution patterns among various tree components for 16 Chinese fir provenances. 

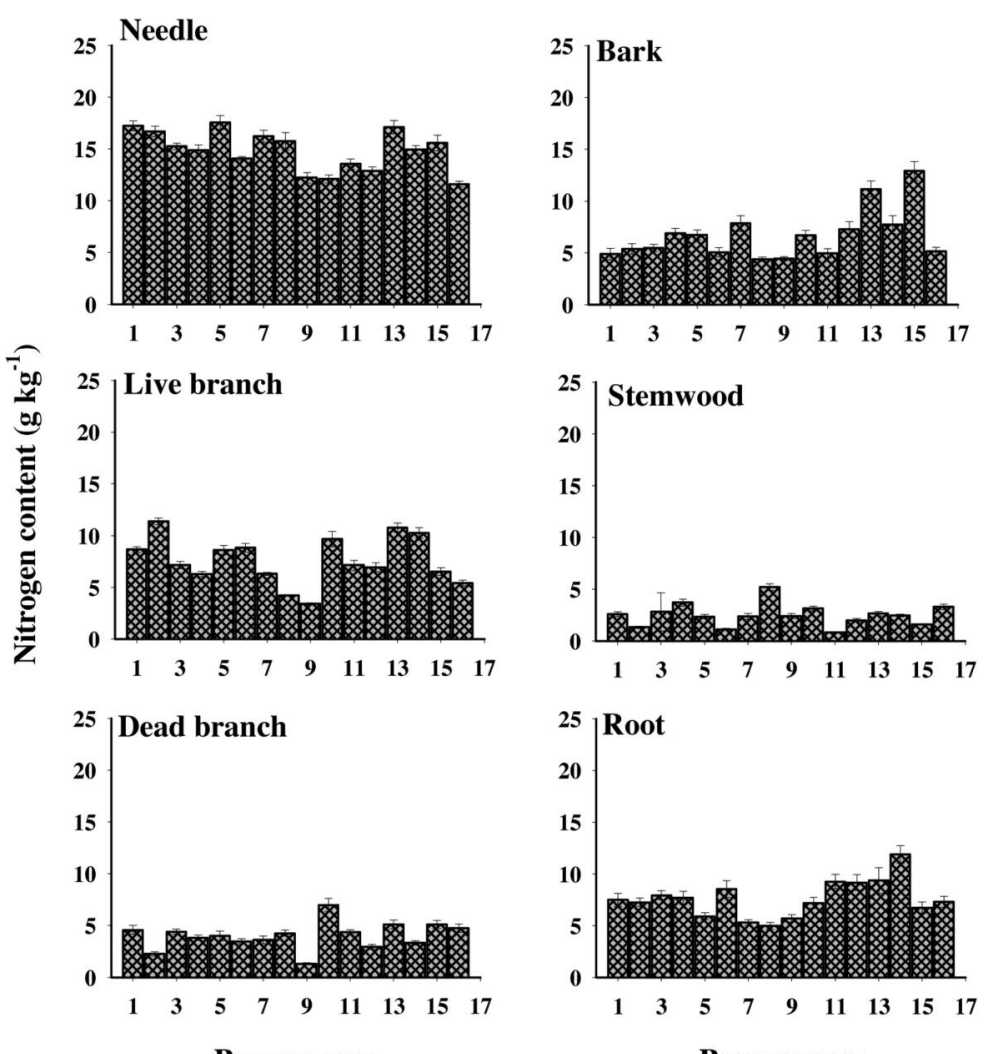

Provenances

Provenances

Figure 4. - Nitrogen content $\left(\mathrm{g} \mathrm{kg}^{-1}\right)$ of various tree components for 16 Chinese fir provenances (mean $\pm \mathrm{se}$ ).

$65.2 \%$ of the total biomass (Figure 3). Percentage contribution of roots to the total biomass ranged from $11.0 \%$ to $24.1 \%$, while that of bark was generally low, 7.4-13.7\%. The contribution of either branches or needles to the total biomass was $\leq 10 \%$. As a whole, the biomass distribution among different tree components was as follows stemwood $>$ root $>$ stembark $>$ live branches $>$ needle $>$ dead branches.

\section{Nutrient content}

The concentration of nitrogen, phosphorus and potassium in various tree components varied significantly among provenances $(\mathrm{p}<0.0001)$, and more that $79 \%$ of the variation was due to provenance (Table 2). The PCV was considerably higher for phosphorus content than the corresponding nitrogen and potassium contents in various tree components. Unlike other tree components, stemwood and dead branches had the highest PCV in phosphorus content. Much of the nitrogen was stored in the needles followed by root, live branches, stembark, dead branches and stemwood, respectively. The mean nitrogen content of needles ranged from $11.6 \pm 0.5$ to $17.5 \pm 0.7 \mathrm{~g} \mathrm{~kg}^{-1}$; of live branches from $3.4 \pm 0.1$ to $11.4 \pm 0.3 \mathrm{~g} \mathrm{~kg}^{-1}$; of dead branches from $1.3 \pm 0.1$ to $7.0 \pm 0.4 \mathrm{~g} \mathrm{~kg}^{-1}$; of stembark from $4.4 \pm 0.1$ to $12.9 \pm 0.5 \mathrm{~g}$ $\mathrm{kg}^{-1}$; of stemwood from $0.8 \pm 0.03$ to $5.2 \pm 0.2 \mathrm{~g} \mathrm{~kg}^{-1}$; of root from $5.0 \pm 0.2$ to $11.9 \pm 0.5 \mathrm{~g} \mathrm{~kg}^{-1}$ (Figure 4). Ranking of provenances with respect to nitrogen content of various tree components was not consistent. Shangcheng, Chenxi, Jinping, and Xuyong had the lowest nitrogen content in needles, branches, stembarks, and stemwood, respectively. Jinping also recorded the lowest value for root nitrogen content. The nitrogen content was the highest in needles for Rongshui, in live branches for Wenshan, in dead branches for Enshi, in stembark for Luoshan, in stemwood for Jinping and in roots for Xiuning.

Much of the phosphorus was stored in the needles, live branches, stembark and root while it was much less in the dead branches and stemwood. The mean phosphorus content ranged between $0.4 \pm 0.01$ and $2.0 \pm 0.1 \mathrm{~g}$ $\mathrm{kg}^{-1}$ for needles; $0.2 \pm 0.01-1.4 \pm 0.1 \mathrm{~g} \mathrm{~kg}^{-1}$ for live branches; $0.04 \pm 0.003-0.9 \pm 0.04 \mathrm{~g} \mathrm{~kg}^{-1}$ for dead branches; $0.2 \pm 0.004-1.5 \pm 0.1 \mathrm{~g} \mathrm{~kg}^{-1}$ for stembark; $0.04 \pm 0.001-0.7 \pm 0.02 \mathrm{~g} \mathrm{~kg}^{-1}$ for stemwood; and $0.2 \pm 0.01-1.2 \pm 0.1 \mathrm{~g} \mathrm{~kg}^{-1}$ for root. Luoshan consistently recorded the highest value for this trait in various tree components while Xiuning, Chenxi, Jiande and Nanping recorded the lowest phosphorus content in needles, dead branches, stemwood and roots, respectively while Quannan had the lowest phosphorus content in live branches and stembark.

The potassium content of the various tree components also varied significantly among provenances, and much of it was stored in the needles followed by live branches, roots and barks while dead branches and stemwood were relatively poor in potassium content. The mean potassium content ranged from $3.4 \pm 0.1$ to $7.1 \pm 0.2 \mathrm{~g}$ $\mathrm{kg}^{-1}$ for needles; $2.2 \pm 0.1-5.3 \pm 0.2 \mathrm{~g} \mathrm{~kg}^{-1}$ for live branches; $0.2 \pm 0.02-1.8 \pm 0.1 \mathrm{~g} \mathrm{~kg}^{-1}$ for dead branches; $1.4 \pm 0.1-4.7 \pm 0.2 \mathrm{~g} \mathrm{~kg}^{-1}$ for stembark; $0.6 \pm 0.02-$ 
Table 3. - N, P, K and overall nutrient use efficiency of 16 Chinese fir provenances based on whole tree estimate $($ Mean $\pm \mathrm{se})$.

\begin{tabular}{|c|c|c|c|c|}
\hline \multirow{2}{*}{ Provenance } & \multicolumn{4}{|c|}{ Whole-tree NUE $\left(\mathrm{g} \mathrm{g}^{-1}\right)$} \\
\hline & $\mathrm{N}$ & $\bar{P}$ & $\mathrm{~K}$ & Overall \\
\hline Pubei & $207.10 \pm 1.02 \mathrm{~d}$ & $1751.51 \pm 6.02 b$ & $538.42 \pm 0.89 \mathrm{~d}$ & $137.81 \pm 0.36 c$ \\
\hline Wenshan & $210.15 \pm 1.80 \mathrm{de}$ & $3599.71 \pm 43.51 \mathrm{ef}$ & $590.57 \pm 3.51 \mathrm{ef}$ & $148.60 \pm 1.20 \mathrm{de}$ \\
\hline Huaiji & $223.21 \pm 4.42 \mathrm{ef}$ & $1735.19 \pm 22.96 b$ & $780.02 \pm 12.53 \mathrm{~h}$ & $157.77 \pm 2.91 \mathrm{ef}$ \\
\hline Changtai & $164.86 \pm 2.67 a$ & $2711.91 \pm 83.48 c$ & $448.16 \pm 9.00 b c$ & $115.39 \pm 2.06 a$ \\
\hline Rongshui & $233.79 \pm 4.19 f g$ & $3896.06 \pm 136.58 \mathrm{fg}$ & $613.74 \pm 13.87 \mathrm{fg}$ & $162.25 \pm 3.23 f$ \\
\hline Quannan & $248.56 \pm 8.19 \mathrm{gh}$ & $5990.31 \pm 119.31 \mathrm{i}$ & $560.13 \pm 19.29 \mathrm{de}$ & $167.35 \pm 5.53 f$ \\
\hline Nanping & $224.80 \pm 0.53 \mathrm{ef}$ & $7011.28 \pm 16.59 j$ & $629.79 \pm 3.46 \mathrm{fg}$ & $161.84 \pm 0.51 f$ \\
\hline Jinping & $183.31 \pm 1.34 b$ & $3462.52 \pm 106.44 \mathrm{e}$ & $641.27 \pm 9.66 \mathrm{~g}$ & $136.91 \pm 1.32 \mathrm{c}$ \\
\hline Chenxi & $254.07 \pm 3.80 \mathrm{~h}$ & $3612.59 \pm 124.85 \mathrm{ef}$ & $489.58 \pm 7.17 c$ & $159.86 \pm 2.51 f$ \\
\hline Enshi & $187.33 \pm 3.86 \mathrm{bc}$ & $1724.37 \pm 16.95 b$ & $463.93 \pm 14.09 b c$ & $123.85 \pm 2.78 \mathrm{ab}$ \\
\hline Xuyong & $273.12 \pm 1.64 i$ & $3243.64+31.51 \mathrm{de}$ & $633.22 \pm 2.70 f g$ & $180.21+1.02 \mathrm{~g}$ \\
\hline Kaihua & $235.32 \pm 6.19 \mathrm{fg}$ & $5306.86 \pm 95.79 \mathrm{~h}$ & $387.22 \pm 4.96 a$ & $142.43 \pm 3.01 \mathrm{~cd}$ \\
\hline Jiande & $164.26 \pm 2.53 \mathrm{a}$ & $2955.75 \pm 105.85 \mathrm{~cd}$ & $543.08 \pm 14.62 d$ & $120.95 \pm 2.27 a b$ \\
\hline Xiuning & $165.22 \pm 2.67 \mathrm{a}$ & $4988.05 \pm 77.06 \mathrm{~h}$ & $431.55 \pm 3.83 b$ & $116.68 \pm 1.65 \mathrm{a}$ \\
\hline Luoshan & $206.30 \pm 1.39 \mathrm{~d}$ & $1042.69=4.56 \mathrm{a}$ & $552.95 \pm 3.53 \mathrm{de}$ & $131.32 \pm 0.83 \mathrm{bc}$ \\
\hline Shangcheng & $199.62 \pm 2.61 \mathrm{~cd}$ & $4142.37 \pm 111.55 \mathrm{~g}$ & $465.73 \pm 13.97 b c$ & $135.15 \pm 2.47 c$ \\
\hline Mean & $211.32 \pm 4.74$ & $3573.43 \pm 233.73$ & $548.09 \pm 14.26$ & $143.65 \pm 2.82$ \\
\hline
\end{tabular}

$2.1 \pm 0.1 \mathrm{~g} \mathrm{~kg}^{-1}$ for stemwood; and $2.5 \pm 0.1-4.3 \pm 0.2 \mathrm{~g}$ $\mathrm{kg}^{-1}$ for root. Ranking of provenances according to potassium content of various tree components was not consistent. Huaiji recorded the lowest values in needles and stembark, Luoshan in stemwood and roots, Chenxi in live branches, and Jiande in dead branches. The highest values for this trait was recorded for Shangcheng in needles, Enshi in live branches, Xuyong in dead branches, Luoshan in stembark, Kaihua in stemwood and Quannan in the roots.

\section{Nutrient-use efficiency}

Nutrient use efficiency for N, P, K and total NUE, based on both whole-tree and stem wood estimates, varied significantly $(\mathrm{p}<0.0001)$ among provenances, and much of the variation was attributed to provenances (Table 2). The PCV was higher for $\mathrm{P}$ use efficiency than $\mathrm{N}$ and $\mathrm{K}$ use efficiencies. In terms of whole-tree nutrient use efficiency, Xuyong was the most efficient provenance for $\mathrm{N}$, and Xiuning and Changtai were the least (Table 3). Most efficient provenances for $\mathrm{P}$ and $\mathrm{K}$ uses were Nanping and Huaiji, respectively while Loshan and Kaihuan were the least efficient provenances (Table 3). While Xuyong was the most efficient in overall NUE,
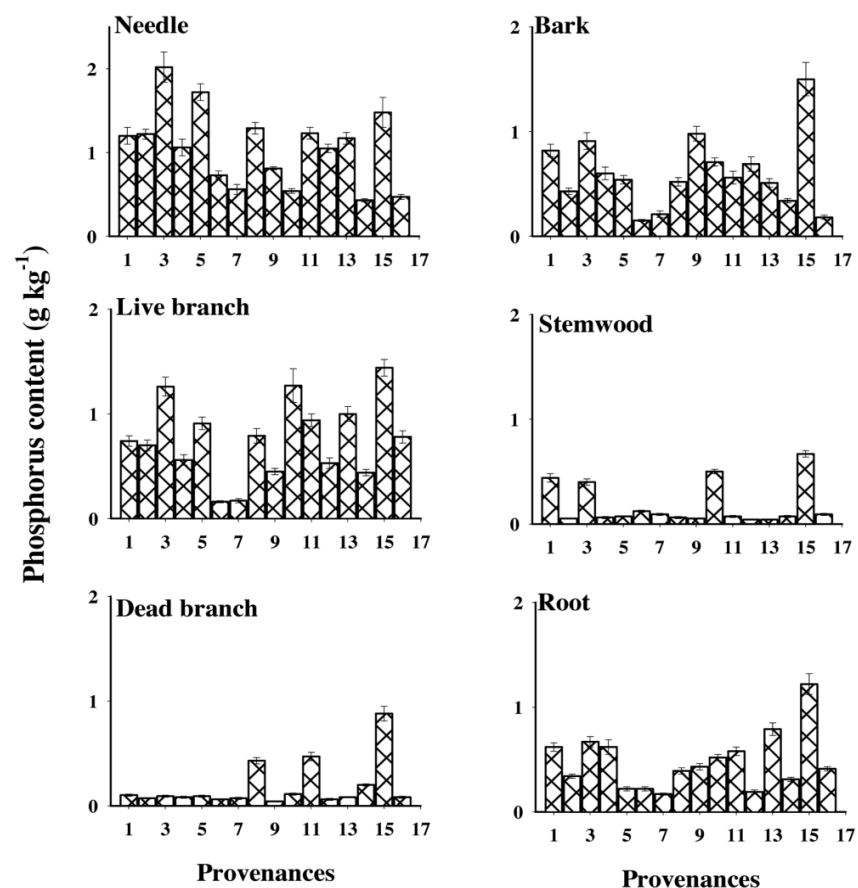

Figure 5. - Phosphorus content $\left(\mathrm{g} \mathrm{kg}^{-1}\right)$ of various tree components for 16 Chinese fir provenances (mean \pm se). 
Table 4. - N, P, K and overall nutrient use efficiency of 16 Chinese fir provenances based on stem wood estimate (Mean $\pm \mathrm{se})$.

\begin{tabular}{|c|c|c|c|c|}
\hline \multirow{2}{*}{ Provenance } & \multicolumn{4}{|c|}{ Stem wood-NUE $\left(\mathrm{g} \mathrm{g}^{-1}\right)$} \\
\hline & $\mathrm{N}$ & $\mathrm{P}$ & $\mathrm{K}$ & Overall \\
\hline Pubei & $122.55 \pm 0.32 \mathrm{def}$ & $1036.44 \pm 11.29 \mathrm{~b}$ & $318.60 \pm 2.91 \mathrm{cde}$ & $81.54 \pm 0.40 \mathrm{cdef}$ \\
\hline Wenshan & $113.41 \pm 1.15 \mathrm{cde}$ & $1942.54 \pm 25.70 \mathrm{~cd}$ & $318.69 \pm 2.54 \mathrm{cde}$ & $80.19 \pm 0.78 \mathrm{cde}$ \\
\hline Huaiji & $143.21 \pm 6.69 \mathrm{fgh}$ & $1112.92 \pm 44.37 b$ & $500.38 \pm 21.52 \mathrm{~g}$ & $101.22 \pm 4.59 \mathrm{~g}$ \\
\hline Changtai & $76.96 \pm 4.31 \mathrm{a}$ & $1267.41 \pm 88.97 b$ & $209.27 \pm 12.51 a$ & $53.87 \pm 3.10 \mathrm{a}$ \\
\hline Rongshui & $152.32 \pm 6.56 \mathrm{gh}$ & $2540.60 \pm 151.86 \mathrm{ef}$ & $399.96 \pm 19.04 \mathrm{f}$ & $105.72 \pm 4.75 \mathrm{~g}$ \\
\hline Quannan & $147.98 \pm 8.47 \mathrm{gh}$ & $3563.90 \pm 157.13 \mathrm{~g}$ & $333.50 \pm 19.59 \mathrm{de}$ & $99.63 \pm 5.71 \mathrm{~g}$ \\
\hline Nanping & $133.55 \pm 1.07 \mathrm{efg}$ & $4165.08 \pm 32.46 \mathrm{~h}$ & $374.15 \pm 4.23 \mathrm{ef}$ & $96.14 \pm 0.85 f g$ \\
\hline Jinping & $102.98 \pm 2.91 \mathrm{bcd}$ & $1947.12 \pm 102.07 \mathrm{~cd}$ & $360.38 \pm 13.21 \mathrm{ef}$ & $76.92 \pm 2.38 \mathrm{bcd}$ \\
\hline Chenxi & $150.58 \pm 4.32 \mathrm{gh}$ & $2142.19 \pm 103.38 \mathrm{cde}$ & $290.15 \pm 8.23 \mathrm{bcd}$ & $94.74 \pm 2.79 \mathrm{efg}$ \\
\hline Enshi & $107.14 \pm 6.61 \mathrm{bcd}$ & $985.41 \pm 50.03 b$ & $265.56 \pm 18.98 \mathrm{abc}$ & $70.85 \pm 4.49 \mathrm{bc}$ \\
\hline Xuyong & $161.09 \pm 1.71 \mathrm{~h}$ & $1913.23 \pm 27.71 \mathrm{~cd}$ & $373.48 \pm 3.27 \mathrm{ef}$ & $106.29 \pm 1.09 \mathrm{~g}$ \\
\hline Kaihua & $151.43 \pm 7.39 \mathrm{gh}$ & $3413.67 \pm 138.69 \mathrm{~g}$ & $249.02 \pm 8.82 \mathrm{ab}$ & $91.63 \pm 4.00 \mathrm{defg}$ \\
\hline Jiande & $96.50 \pm 3.69 \mathrm{abc}$ & $1738.09 \pm 102.02 \mathrm{c}$ & $319.22 \pm 15.89 \mathrm{cde}$ & $71.07 \pm 3.00 \mathrm{bc}$ \\
\hline Xiuning & $88.95 \pm 4.09 \mathrm{ab}$ & $2685.24 \pm 121.69 f$ & $232.23 \pm 8.99 \mathrm{ab}$ & $62.81 \pm 2.76 \mathrm{ab}$ \\
\hline Luoshan & $115.98 \pm 2.61 \mathrm{cde}$ & $586.16 \pm 11.89 a$ & $310.87 \pm 6.89 \mathrm{cde}$ & $73.83 \pm 1.64 \mathrm{bc}$ \\
\hline Shangcheng & $112.86 \pm 4.76 \mathrm{cde}$ & $2343.64 \pm 128.72 \mathrm{def}$ & $263.56 \pm 15.43 \mathrm{abc}$ & $76.43 \pm 3.62 \mathrm{bcd}$ \\
\hline Mean & $123.59 \pm 3.76$ & $2086.48 \pm 143.87$ & $319.94 \pm 10.57$ & $83.93 \pm 2.33$ \\
\hline
\end{tabular}
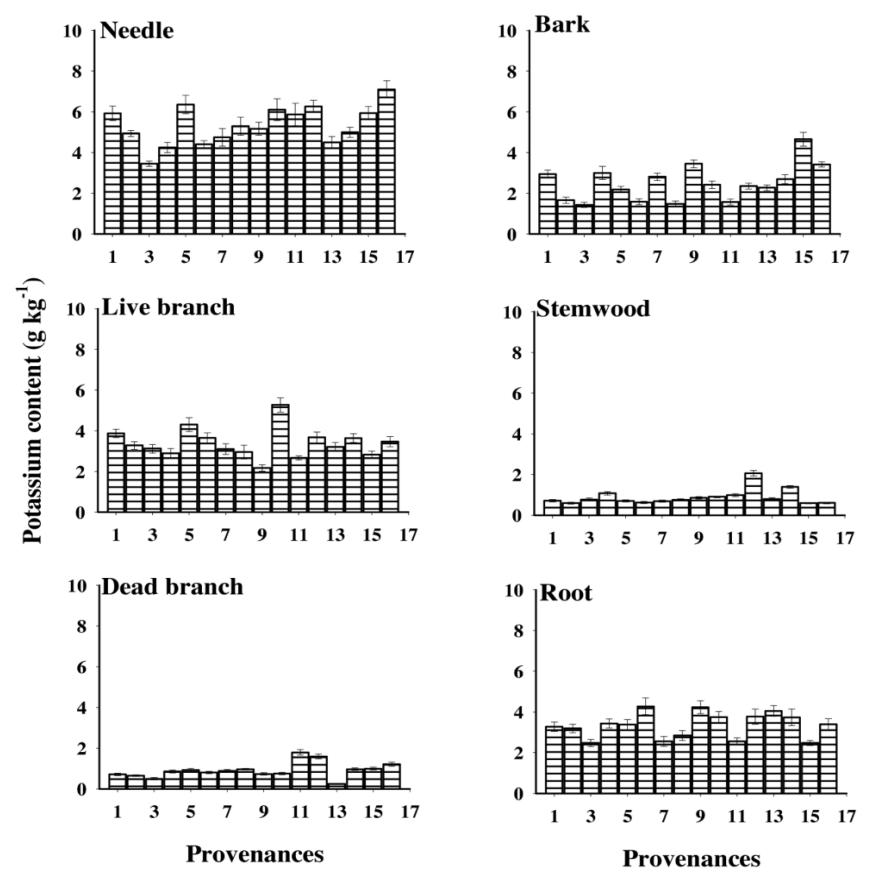

Xiuning and Changtai were the two least efficient provenances (Table 3). It is interesting to note that the overall NUE followed a similar order as that of nitrogen use efficiency, implying the leading role of nitrogen use in deciding total nutrient use efficiency, as $\mathrm{N}$ accounted approximately $62-75 \%$ of the total nutrient content.

Viewed from the point of stem wood nutrient use efficiency, Xuyong again ranked the best in nitrogen use efficiency followed by Quannan, Wenshan and Luoshan, while Changtai was the least efficient provenance (Table 4). With regard to $P$ use efficiency, Nanping appeared to be the most efficient while Luoshan, a provenance from the most northern, represented the least $\mathrm{P}$ use efficiency. The $\mathrm{K}$ use efficiency was the greatest in Huaiji, but the least in Changtai.

\section{Discussion}

In general, determinants of patterns of genetic variation in plant populations are extremely varied and involve complex interactions between plant attributes, such as life form, floral architecture, modes of reproduction, mating system, and ecological and environmental factors that may influence pollination events, population

Figure 6. - Potassium content $\left(\mathrm{g} \mathrm{kg}^{-1}\right)$ of various tree components for 16 Chinese fir provenances (mean $\pm \mathrm{se})$. 
size and isolation (HAMrick et al., 1992; ProBer and BROWN, 1994; COATES and BYRNE, 2005). In addition, the large heterogeneity in environmental conditions within the natural range of distribution of the species would favor monomorphic, specialized and genetically different populations while heterogeneity in time of reproductive events may lead to polymorphy within populations. In fact, a range wide provenance variation observed in growth, photosynthesis, and transpiration of Chinese fir (YU, 1997; SHEN et al., 1994) is an indicator for the existence of genetic variation for a number of other traits. Substantial genetic variation among natural populations for a variety of quantitative traits has been documented for economically useful tropical plantation species such as Cordia africana Lam. (LOHA et al., 2006, 2009), Millettia ferruginea (Hochst.) Baker (LOHA et al., 2008), Vitellaria paradoxa C.F. Gaertn. (LAMIEN et al., 2007), Gmelina arborea Roxb. (LAURIDSEN, 2004; HodGE and DVORAK, 2004), Tectona grandis L.f. (JAYASANKAR et al., 1999) and Hevea brasiliensis (Willd. ex Adr. de Juss) Muell.-Arg. (AlIKA, 1980).

The occurrence of Chinese fir over a wide geographical range, encompassing a great diversity in edapho-climatic conditions of its habitat, is expected to be reflected in the genetic constitution of its diverse populations. In the present study, a considerable variation in biomass, nutrient content and NUE was observed among provenances, and most of the total variation was a provenance effect (Table 2). Differences in local topography and regional environment as well as geographical and ecological isolations generally account for variation in biomass productivity among Chinese fir provenances (ANONYMOUS, 1994). Within the provenance region, the growth and productivity of Chinese fir declines gradually from central habitat to boundary area with varied geography and eco-climatic conditions, thus lead to quantitative and qualitative differences in biomass and wood production among provenances within the region. As a whole, the variation among provenances indicates that there is a great scope for further selection of genotypes to enhance productivity of Chinese fir in shortrotation plantations.

From total biomass production viewpoint, Changtai and Wenshan from the southern range and Xiuning from the northern range of distribution of Chinese fir performed best. Generally, growth of Chinese fir declines towards the northern range of its distribution. However, provenances from the south and north performed well in terms of biomass production when planted in the central distribution region. This is in line with the fact that when species move to a "new" environment, they express their full genetic potential for growth. However, the prime goal in short-rotation forestry is to produce a good quality timber in the shortest possible time. In this regard, Xiuning, Chenxi, Rongshan and Wenshan would be the target provenances for future planting on sites similar to the study area, as they have the highest stemwood biomass.

High biomass production obviously is an important consideration in all commercial tree-planting programs. However, provenances should not be selected only on growth traits but also on the nutrient cost of biomass removed by harvesting (KUMAR et al., 1998). Nutrient use efficiency provides a good measure to evaluate the differences in nutrient costs of biomass production (WANG et al., 1991; KUMAR et al., 1998). Provenance selection that considers nutrient use efficiency, therefore, is a potential tool available to the forest managers to limit the cost of fertilizing needed to maintain stand growth and soil fertility. There is also growing evidence pointing to yield reduction and carbon stock change in successive rotation of Chinese fir plantations due to depletion of the soil fertility (e.g. CHEN, 1983; FANG, 1987; MA et al., 2003; ZHANG et al., 2004). Thus, provenances that are not only yielding good stemwood but also efficient in their nutrient use should be considered in future planting. For this purpose, Rongshui and Chenxi appear to be the best candidate in terms of both overall nutrient use efficiency and stemwood production. Xuyong is, however, the most efficient of all provenances in terms of nitrogen use efficiency and overall nutrient use efficiency, thus it can be planted on poor sites despite its low biomass and stemwood production.

Given their high nitrogen use efficiency, Chenxi, Quannan, Rongshui and Kaihua can be suitable provenances for planting on nitrogen-deficient sites while Hauiji, Jinping, Rongshui and Nanping are suitable for potassium-limited sites. Available phosphorus is the major growth limiting factor in Chinese fir plantation areas (Wu et al., 2001). For such areas, Nanping, Quannan, Kaihua and Xiuning would be the target source of planting materials, as they are the most efficient in their phosphorus use. On the contrary, Luoshan exhibited the greatest concentrations of $\mathrm{P}$ in various tree components despite better NUE for N and K. Consequently, choosing Luoshan to plant in the south subtropic zone where the soil is limited in phosphorus availability would aggravate/accelerate depletion of soil $\mathrm{P}$.

Stemwood has made up the main part of the total stand biomass in all provenances, thus nutrients stored in the stemwood could not be small. Hence, the current harvesting practices for Chinese fir plantations of clearcutting all trees at the same time and removing the stems (and bark), which contain $68 \%$ of the tree biomass nutrient store, may cause nutrient depletion of the site. It is therefore recommended that the harvest residues (needles, branches and roots) are retained on the site (as is currently practiced) in order to maximize the retention of nutrients at the site. It should be noted that a considerable amount of nutrients $(\mathrm{N}, \mathrm{P}$, and $\mathrm{K})$ is stored in the needles, branches and roots irrespective of the provenances. Nutrient turnover time (the time taken for $95 \%$ of the litter to decompose) of Chinese fir litter is slow and hence the nutrients in litterfall are not instantly available to the tree (MA et al., 2007). Thus proper management of harvest residue for enhanced recycling of nutrients back to the soil should be designed.

\section{Conclusions}

The study reveals the existence of considerable variation in biomass, nutrient content and nutrient use effi- 
ciency among Chinese fir provenances, which can be exploited further for selecting desirable genotypes for enhancing productivity of Chinese fir plantations. The fact that none of the provenances displayed consistent variation for biomass, nutrient content and NUE suggests the need for multiple criteria for selection in future tree improvement program. As this study is based on single planting site, further genotype $\times$ location study is recommended to select genotypes suitable for different purposes and site conditions.

\section{Acknowledgements}

This study was financially supported by the National Natural Science Foundation of China (Grant Nos. 30970451 and 30972354). Authors are grateful to the scientists involved in the breeding program in Xiqin for providing all facilities for the harvest of the provenances test: YUSHUO GUO; AIQIN LI and LIPING CAI for laboratory analyses; and JiAN JiANG and XIAOLONG HOU for data compilation.

\section{References}

AERTS, R. (1990): Nutrient use efficiency in evergreen and deciduous species from heathlands. Oecologia 84: 391-397.

AlIKA, J. E. (1980): Genetic variation among Nigerian Havea provenances. Silvae Genetica 29: 201-205.

ANONYMOUs (1991): Selecting and applying fine strain origins of Cunninghamia lanceolata in afforestation districts of Zhejiang province. Cooperative group of Cunninghamia lanceolata research in Zhejiang. Journal of Zhejiang Forest Science \& Technology 11: 31-38 (in Chinese, with English abstract).

ANONYMOUS (1994): Study on division of Chinese fir provenance. National Cooperative Group of Chinese fir Provenance Test. Forest research - memoir of Chinese fir provenance test 7: 130-144 (in Chinese, with English abstract).

CHEN, L. (1983): Effects of successive rotation on the growth of Chinese fir and soil fertility in Yongshui of Guangxi Province. Guangxi Journal of Forestry Invention 12(1): 17-25 (in Chinese).

CoATES, D. J. and M. BYRne (2005): Genetic variation in plant populations: assessing cause and pattern, pp. 139-164. In: Plant Diversity and Evolution: Genotypic and phenotypic variation in Higher Plants, edited by $R$. J. HEnRY, CABI Publishing, Wallingford / Massachusetts.

FANG, Q. (1987): Influences of continuous cropping on soil fertility and stand growth in Chinese fir plantation. Scientia Silvae Sinicae 23(4): 389-397 (in Chinese, with English abstract).

Hamrick, J. L., M. J. Godt and S. L. Sherman-Broyles (1992): Factors influencing levels of genetic diversity in woody plant species. New Forests 6: 92-124.

HERBERT, M. A. (1996): Fertilizers and Eucalypt plantations in South Africa, pp. 303-325. In: Nutrition of Eucalypts, edited by P. M. AtTiwill and M. A. AdAms, CSIRO, Australia.

Hodge, G. R. and W. S. DvoraK (2004): The CAMCORE international provenance/progeny trials of Gmelina arborea: genetic parameters and potential gain. New Forests 28: 147-166.
JACKsON, M. L. (1958): Soil Chemical Analysis. PrenticeHall, Englewood Cliffs, NJ.

Jayasankar, S., L. C. Babu, K. Sudhakar and V. K. G. UNNITHAN (1999): Provenance variation in seed and germination characteristics of teak (Tectona grandis L.F.). Seed Science and Technology 27: 131-139.

Kumar, B. M. S. J. George, V. Jamaludheen and T. K. SURESH (1998): Comparison of biomass production, tree allometry and nutrient use efficiency of multipurpose trees grown in woodlot and silvopastoral experiments in Kerala, India. Forest Ecology and Management 112: 145-163.

Lamien, N., M. Tigabu, S. Guinko and P. C. Oden (2007): Variations in dendrometric and fruiting characters of Vitellaria paradoxa populations and multivariate models for estimation of fruit yield. Agroforestry Systems 69: $1-11$.

LAURIDSEN, E. B. (2004): Features of some provenances in an international provenance experiment of Gmelina arborea. New Forests 28: 127-145.

Li, X., L. Huang, L. Sun, K. Fan, X. Du, Y. Jin, J. Lv, Z. HuA, H. Lu, C. Sun and G. XIE (1993): Study on elite provenance selection of Cunninghamia lanceolata for short rotation timber. Journal of Jiangsu Forestry Science \& Technology 3: 1-7 (in Chinese, with English abstract).

LI, X., L. HuANG, Y. LI, Z. HuA and Y. Wu (1994): Geographic variation in trunk wood and aboveground biomass among various Chinese fir provenances, J Jiangxi Forestry Science \& Technology 149(3-4): 128-133 (in Chinese, with English abstract).

Loha, A., M. Tigabu, D. Teketay, K. Lundkvist and A. FRIES (2006): Provenance variation in seed morphometric traits, germination and seedling growth of Cordia africana Lam. New Forests 32: 71-86.

LOHA, A., M. TIGABU and A. FRIES (2008): Variability in seed- and seedling-related traits of Millettia ferruginea, a potential agroforestry species. New Forests 36: 67-78.

LoHA, A., M. TigabU and A. Fries (2009): Genetic variation among and within populations of Cordia africana in seed size and germination responses to constant temperatures. Euphytica 165: 189-196.

MA, X., A. LIU, Z. MA and S. FAN (2000a): A comparative study on nutrient accumulation and distribution of different generations of Chinese fir plantation. Chinese Journal of Applied Ecology 11(4): 501-506 (in Chinese, with English abstract).

MA, X., S. FAN, A. LIU, S. CHEN and S. LIN (2000b): A comparison on soil fertilities of Chinese fir plantations of different generations. Forestry Research 13(6): 577-582 (in Chinese, with English abstract).

MA X., S. KANG, Y. HuAng, K. Lin and S. FAN (2002): Effects of multi-rotation of Chinese fir plantations on granite sites. Journal of Fujian College of Forestry 22(4): 289-294 (in Chinese, with English abstract).

MA, X., K. V. HEAL, A. LIU and P. G. JARVIS (2007): Nutrient cycling and distribution in different-aged plantations of Chinese fir in southern China. Forest Ecology and Management 243: 61-74.

MisRA, R. (1968): Ecology Work Book. Oxford and IBH Publishing, Calcutta.

Peach, K. and M. V. TRacy (1956): Modern Methods of Plant Analysis. Springer/Verlag, Berlin.

Prober, S. M. and A. H. D. BRown (1994): Conservation of the grassy white box woodlands: Population genetics and fragmentation of Eucalyptus albens. Conservation Biology 8: 1003-1013. 
Shen, X., C. Hong, J. Xu, Y. Wu, G. XIA and G. XU (1994): Study on geographic variability of Cunninghamia lanceolata provenance. Journal of Zhejiang Forestry Science \& Technology 14: 20-24 (in Chinese, with English abstract).

SHENG, W. and S. FAN (2005): Long term productivity of Chinese fir plantations. Science press, Beijing (in Chinese).

Shujauddin, N. and B. M. Kumar (2003): Ailanthus triphysa at different densities and fertilizer regimes in Kerala, India: growth, yield, nutrient use efficiency and nutrient export through harvest. Forest Ecology and Management 180: 135-151.

SUN, Q., C. YANG and R. JIAO (2003): The changes of soil properties of the successive Chinese fir plantation in Dagang Mountain of Jiangxi Province. Scientia Silvae Sinicae 39(3): 1-5 (in Chinese, with English abstract).

TIAN, D., W. XIANG, W. YAN and W. KANG (2002): Effect of successive rotation on productivity and biomass of Chinese fir plantation at fast growing stage. Scientia Silvae Sinicae 38(4): 14-18 (in Chinese, with English abstract).

VitouseK, P. M. (1982): Nutrient cycling and nutrient efficiency. The American Naturalist 119(4): 553-572.

Wang, D., F. H. Bormann, A. E. Lugo and R. D. Bowden (1991): Comparison of nutrient-use efficiency and biomass production in five tropical tree taxa. Forest Ecology and Management 46: 1-21.

Wu, Z. (1984): Chinese Fir. Chinese Forestry Press, Beijing (in Chinese).

Wu, W., T. Zhang, C. Gao, B. Sun, B. Peng and Q. ZhaO (2001): Changes of soil fertility quality properties under artificial Chinese fir forest in red soil region. Acta Pedologica Sinica 38(3): 285-294.

YANG, C., X-Q ZHANG and R. JIAO (1996): Variations of chemical properties, biochemical, microorganism activities and function in soil of successive rotation of Chi- nese fir and their influences on growing. Scientia Silvae Sinicae 32(2): 175-181 (in Chinese, with English abstract).

YANG, Y., G. Chen, J. XIE and X. YU (2000): Effect of harvesting and cleaning on nutrition in Chinese fir plantation. Journal of Natural Resources 15: 133-137 (in Chinese, with English abstract).

YANG, Y., D. Ye, X. YU and G. Chen (1999): Stand biomass in different rotations of Chinese fir. Journal of Northeast Forestry University 27: 9-12 (in Chinese, with English abstract).

YING, J. (1997): Comparative study on the growth and soil properties under different successive rotation of Chinese fir. Journal of Jiangsu Forestry Science and Technology 24(1): 31-34 (in Chinese, with English abstract).

YING, J., Z. HE, S. FAN, H. SU and H. LIAN (2004): Research on biomass and its distribution of a 29-yearold, first rotation Chinese fir plantation, Journal of Fujian Forestry College 21: 339-342 (in Chinese, with English abstract).

Yu, X. (1997): Chinese Fir Silviculture. Fujian Science and Technology Press, Fuzhou (in Chinese).

YU, X. and Q. ZHANG (1989): Study on soil biochemical character and its fertility in the successive planting site of Chinese fir plantation. Journal of Fujian Forestry College 9: 263-271 (in Chinese, with English abstract).

Yu, Y., X. Deng, W. Sheng, S. FAn, Q. Lin and L. Lei (2000): Effects of continuous plantation of Chinese fir on soil physical properties. Journal of Nanjing Forestry University 24(6): 36-40 (in Chinese, with English abstract).

Zhang, X-Q., M. U. F. Kirschbaum, Z. Hou and Z. Guo (2004): Carbon stock changes in successive rotations of Chinese fir (Cunninghamia lanceolata (Lamb) Hook) plantations. Forest Ecology and Management 202: 131-147.

\title{
Genetic parameter estimates and parental selection in Eucalyptus longirostrata and Corymbia henryi populations tested in South Africa
}

\author{
By TAMmY-L. SwaIN*) and ANDREA K. LOUw ${ }^{1)}$
}

Institute for Commercial Forestry Research, P.O. Box 100281, Scottsville, Pietermaritzburg 3209, South Africa

(Received $15^{\text {th }}$ February 2010)

\begin{abstract}
The sub-tropical species, Eucalyptus longirostrata (formerly E. punctata var longirostrata) and Corymbia henryi were investigated as alternative species for

\footnotetext{
1) Sappi Forests Research, Shaw Research Centre, P O Box 473, Howick 3290, South Africa.

*) Author for correspondence: TAMmY-L. SwAIN.

Telephone: +27 33386 2314, Fax: +27 333868905 .

E-mail: Tammy.Swain@icfr.ukzn.ac.za
}

growth on the Zululand coastal plain in South Africa. Provenance/progeny trials were established in 2001 at two sites, namely, Nyalazi and Kwambonambi. The seed material purchased from the Commonwealth Scientific and Industrial Research Organization in Australia in 2000 included six provenances of $E$. longirostrata and five provenances of $C$. henryi. Six-year diameter at breast height measurements were completed in 2007. Individual narrow-sense heritability coefficients for diameter growth varied from 0.30 to 0.58 for both species, with heritabilities being higher at the drier 